\author{
DOI: 10.12731/wsd-2017-2-24-40 \\ УДК 577.352.335:618.14-002
}

\title{
БЕЛКОВО-ЛИПИДНЫЙ СОСТАВ МЕМБРАНЫ И МЕТАБОЛИЗМ ЭРИТРОЦИТОВ ПРИ ХРОНИЧЕСКОМ ЭНДОМЕТРИТЕ
}

\author{
Суняйкина О.А., Конопля Н.А., Сергеева С.Л., Барсук А.А.
}

Цель. Установить изменения белково-липидного спектра мембраны эритроцитов при ХЭ до и после традиционного комплексного лечения.

Материалы и методы. У 38 пачиенток репродуктивного возраста с верифицированным диагнозом хронический эндометрит в стадии неполной ремиссии, получавших комплексное традиционное лечение, включающее оперативное вмешательство по поводу бесплодия, изучены параметры структурно-функциональных свойств эритроциитов до и после лечения.

Результаты. До начала лечения установлены значительные изменения в содержании белков, ответственных за структурообразование и стабилизацию мембраны эритроцитов ( $\alpha$ - и $\beta$-спектрин, дематин, анкирин, белок полосы 4.1, паллидин), формообразование и гибкость мембраны (актин, тропомиозин), внутриклеточный метаболизм (анионтранспортный белок, глицеральальдегид-3-фосфатдегидрогеназа, глутатион-S-трансфераза). Выявлены нарушения в содержсании и соотномении липидного спектра, в первую очередь, снижение содержания мембранных глицерофосфолипидов и сфингомиелинов, составляющих основу двойного липидного каркаса клеточной мембраны и играющих основную роль в упорядочивании белковых макромолекул и нормальном метаболизме эритроцитов. Определено внутриэритроцитарное повышение процессов перекисного окисления липидов и содержания стабильных метаболитов оксида азота, снижение активности ферментов антиоксидантной защиты. После проведенного лечения нормализовалось 9\% измененных до лечения параметров, корригировано, но не значений нормы, 55,6\%, без изменений осталось $33,4 \%$ показателей.

Ключевые слова: хронический эндометрит; нарушения структурно-функииональных свойств эритрочиттов; белково-липидный состав мембраны. 


\title{
PROTEIN-LIPID COMPOSITION OF ERYTHROCYTE MEMBRANES AND METABOLISM IN CHRONIC ENDOMETRITIS
}

\author{
Sunyakina O.A., Konoplya N.A., Sergeeva S.L., Barsuk A.A.
}

Background: Establishment of changes in protein-lipid spectrum of erythrocyte's membrane in CE before and after traditional complex treatment.

Materials and methods: At 38 patients in reproductive age with verified diagnosis of chronic endometritis in stage of incomplete remission, treated by traditional treatment complex, what included surgical intervention about sterility, were studied parameters of structural-functional properties of erythrocytes before and after treatment.

Results. Before treatment were established considerable changes in composition of proteins, what is in charge for structure formation and stabilization of erythrocyte's membrane ( $\alpha$ - and $\beta$-spectrin, dematin, ancirin, protein of a strip 4.1, pallidin), formation and flexibility of membrane (actin, tropomyosin), intracellular metabolism (anion-transporting protein, glyceraldehyde-3-phosphate dehydrogenase, glutathione-S-transferase). Were revealed disorders in maintenance and correlation of lipid spectrum, in the first place lowering of maintenance of membrane glycerophospholipids and sphingomyelins, what form base of double lipid carcass of cell membrane and play main role in arrangement of protein macromolecules and normal metabolism of erythrocytes. Defined intracellular increase of lipids peroxidation processes and maintenance of nitrogen oxides stable metabolites, lowering of activity of antioxidant defense. After treatment $9 \%$ of changed before treatment parameters were normalized, corrected, but not to normal reference ranges, $55,6 \%, 33,4 \%$ of indices remained the same.

Keywords: chronic endometritis; disorders of structural-functional properties of erythrocytes; protein-lipid composition of erythrocyte membranes.

\section{Введение}

Хронический эндометрит (ХЭ), несмотря на многочисленность исследований и сведений о его значительной распространенности (60-65\%), продолжает привлекать внимание отечественных и зарубежных специалистов. В настоящее время актуальность проблемы данного заболевания 
приобретает не только медицинское, но и социальное значение, поскольку данное заболевание часто приводит к нарушению репродуктивной функции, являясь причиной бесплодия, неудачных попыток экстракорпорального оплодотворения, не вынашивания беременности, осложненного течения беременности и родов [1, с. 690-695, 2, с. 40-45].

В настоящее время ХЭ рассматривается как сложный волнообразный воспалительный процесс, при котором происходит активация широкого спектра факторов, индуцирующих каскадные повреждения с вовлечением различных структур. На фоне длительного воспалительного процесса в эндометрии формируется самоподдерживающаяся патологическая система с интенсивными склеротическими процессами, повреждением экстрацеллюлярного матрикса, нарушением медиаторных межклеточных взаимодействий, изменением ангиоархитектоники тканей и ишемией. На этом фоне иммунный барьер слизистой оболочки матки неполноценен и условно-патогенная микрофлора в полости матки может со временем становиться ведущим микробным фактором обострения хронического эндометрита [2, с. $40-45,3$, с. $289-307,4$, с. $16-18]$.

Известны нарушения содержания и соотношения белков и липидов мембраны эритроцитов при гинекологических заболеваниях [5, с. 5-36], но учитывая, что в литературе не освещены вопросы патогенетической роли эритроцитов в возникновении и развитии ХЭ и не изучена возможность фармакологической коррекции этих нарушений целью настоящего исследования стало установление изменений белково-липидного спектра мембраны эритроцитов при ХЭ до и после традиционного комплексного лечения.

\section{Материал и методы}

Под постоянным наблюдением в гинекологическом отделении Курского городского родильного дома находились 38 пациенток репродуктивного возраста (18-35 лет). Включение больных в исследование осуществлялось на основании информированного согласия. Всем пациенткам проводили комплексное клинико-инструментальное обследование по общепринятым стандартам, при этом во всех случаях имела место верификация диагноза хронический эндометрит в стадии неполной ремиссии. У всех женщин отсутствовали сопутствующие заболевания или они были в стадии ремиссии, всем было проведено эндоскопическое оперативное вмешательство по поводу эндометрит-ассоциированного бесплодия. В после операционном периоде пациентки получали традици- 
онное лечение. Изучены также лабораторные показатели в эритроцитах 16 здоровых женщин того же возраста, сформировавших контрольную группу.

До начала комплексного лечения и после него получали эритроциты из 10 мл гепаринизированной крови, после центрифугирования отделяли плазму, а эритроцитарную массу подвергали очистке на хроматографической колонке через HBS-целлюлозу, после чего определяли сорбционную способность эритроцитов (ССЭ) [6, с. 22-24] и сорбционную емкость их гликокаликса (СЕГ) [7, с. 113-118]. Мембраны эритроцитов выделяли методом G.T. Dodge [8, с. 119-130], липиды мембран определяли методом тонкослойной хроматографии [9, с. $205-$ 206]. Электрофорез белков проводили в присутствии додецилсульфата натрия в вертикальных пластинах полиакриламидного геля по методу U.K. Laemmli [10, с. 680], белки окрашивали Кумаси голубым R-250. Интенсивность процессов перекисного окисления липидов (ПОЛ) оценивали по содержанию в эритроцитах ацилгидроперекисей (АГП) и малонового диальдегида (МДА), образующих с тиобарбитуровой кислотой окрашенный комплекс. Определение МДА и АГП проводили с помощью набора «ТБК-Агат» («Агат-Мед» Россия), при использовании спектрофотометра «Апель-330» (Япония) при длине волны 535 нм и 570 нм. Для оценки состояния антиоксидантной системы определяли методом прямого/конкурентного твердофазного иммуноферментного анализа (ИФА) с детекцией продуктов реакции в диапазоне длины волны 405-630 с применением готовых коммерческих наборов: активность супероксиддисмутазы (СОД) «Bender Medsystems» (Австрия) и каталазы «Cayman Chemical» (США). Общую антиокислительную активность (OАA), определяли методом, основанным на степени ингибирования аскорбат- и ферроиндуцированного окисления твина-80 до МДА. Уровень стабильных метаболитов оксида азота $\left(\mathrm{CM}_{\mathrm{ON}}\right)$ выявляли с использованием двух аналитических операций: измерение эндогенного нитрита и превращение нитрата в нитрит с использованием нитрит-редуктазы с последующим измерением общего нитрита по абсорбции азокрасителя в реакции Грисса при длине волны 540нм с применением коммерческого набора для твердофазного ИФА фирмы «R\&D» (Англия). Регистрация всех результатов ИФА осуществлялась при помощи микропланшетного фотометра «Sunrise», Тесаn (Австрия).

Статистическую обработку результатов исследования проводили по общепринятым критериям вариационно-статистического анализа с вы- 
числением средних величин (M), ошибки средней арифметической (m) с помощью пакета компьютерных программ Microsoft Excel, 2010. Существенность различий оценивали по U-критерию Манна-Уитни. Статистически значимыми считали различия при $\mathrm{p}<0,05$.

\section{Результаты исследования и их обсуждение}

При ХЭ до лечения установлено снижение в эритроцитарной мембране уровня $\alpha$ - и $\beta$-спектрина, анкирина, анионтранспортного белка (АТБ), паллидина, дематина, глицеральальдегид-3-фосфатдегидрогеназы (Г-3-ФД) и глутатион-S-трансферазы (Г-S-T), повышение содержания белка полосы 4.1, актина и тропомиозина при нормальном уровне белка полосы 4.5. Проведенное оперативное и фармакологическое лечение нормализует представительность в мембране эритроцитов $\alpha$ - и $\beta$-спектрина и тропомиозина, корригирует, но не до параметров нормы, содержание анкирина, паллидина, дематина и актина, не влияет на уровень АТБ, белка полосы 4.1, Г-3-ФД и Г-S-Т (табл. 1).

Таблица 1 .

Белки мембраны эритроцитов у пациенток с ХЭ до и после лечения (M $\pm \mathbf{m})$

\begin{tabular}{|c|c|c|c|}
\hline \multirow{2}{*}{ Показатели } & 1 & 2 & 3 \\
\cline { 2 - 4 } & \multirow{2}{*}{ Здоровые } & \multicolumn{2}{|c|}{ Больные } \\
\cline { 3 - 4 } & & До лечения & После лечения \\
\hline$\alpha$-спектрин & $102,4 \pm 2,7$ & $92,8 \pm 2,3^{* 1}$ & $97,4 \pm 2,0^{* 2}$ \\
\hline$\beta$-спектрин & $120,1 \pm 3,6$ & $102,9 \pm 2,4^{*_{1}}$ & $119,5 \pm 2,5^{*_{2}}$ \\
\hline Анкирин & $94,2 \pm 1,6$ & $37,8 \pm 1,9^{* 1}$ & $46,6 \pm 2,4^{* 1,2}$ \\
\hline АТБ & $175,4 \pm 3,3$ & $191,6 \pm 4,3^{* 1}$ & $193,5 \pm 3,7^{* 1}$ \\
\hline 4.1 & $42,4 \pm 1,6$ & $82,5 \pm 1,7^{* 1}$ & $78,2 \pm 1,9^{* 1}$ \\
\hline Паллидин & $92,4 \pm 2,8$ & $47,4 \pm 1,4^{* 1}$ & $59,4 \pm 2,2^{* 1,2}$ \\
\hline 4.5 & $101,5 \pm 2,7$ & $107,4 \pm 4,5$ & $102,1 \pm 3,9$ \\
\hline Дематин & $68,3 \pm 1,9$ & $21,9 \pm 1,1^{* 1}$ & $31,9 \pm 1,8^{* 1,2}$ \\
\hline Актин & $78,5 \pm 1,6$ & $90,4 \pm 1,9^{* 1}$ & $84,4 \pm 2,2^{* 1,2}$ \\
\hline Г-3-ФД & $47,8 \pm 2,1$ & $29,3 \pm 1,5^{* 1}$ & $32,5 \pm 1,8^{* 1}$ \\
\hline Тропомиозин & $48,7 \pm 1,5$ & $62,9 \pm 2,1^{* 1}$ & $50,2 \pm 1,7^{* 2}$ \\
\hline Г-S-Т & $68,6 \pm 1,4$ & $47,2 \pm 1,3^{* 1}$ & $51,6 \pm 2,3^{* 1}$ \\
\hline
\end{tabular}

Примечание: на этой и таблицах 2 и 3 звездочкой отмечены достоверные отличия средних арифметических $(\mathrm{p}<0,05)$; цифры рядом со звездочкой - по отношению к показателям какой группы даны отличия. В этой и таблице 2 единицы измерения показателей - мг\%. 
При поступлении в клинику у больных ХЭ выявлено снижение в эритроцитарной мембране содержания фосфатидилхолина $(\Phi \mathrm{X})$, фосфатидилсерина (ФС), фосфатидилинозитола (ФИ), глицерофосфолипидов (ГФЛ - сумма ЛФХ, ФХ, ФЭ, ФС и ФИ), сфингомиелина (СМ), фосфолипидов (ФЛ - сумма ГФЛ и СМ), повышение уровня лизофосфатидилхолина (ЛФХ), холестерола (X), эфиров холестерола (ЭХ) и триацилглицеролов (ТАГ), при нормальном содержании фосфатидилэтаноламина (ФЭ), суммы моно- и диацилглицеролов (МАГ, ДАГ) и неэстерифицированных жирных кислот (НЭЖК). Проведенное комплексное лечение приближает к параметрам здоровых доноров ЛФХ, ФС, ФИ, ГФЛ, СМ и ФЛ, но не влияет на представительность ФХ, Х, ЭХ и ТАГ (табл. 2).

Таблица 2.

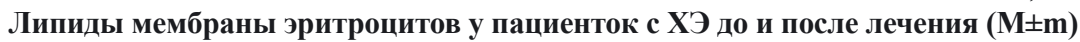

\begin{tabular}{|c|c|c|c|}
\hline \multirow{3}{*}{ Показатели } & 1 & 2 & 3 \\
\hline & \multirow{2}{*}{ Здоровые } & \multicolumn{2}{|c|}{ Больные } \\
\hline & & До лечения & После лечения \\
\hline$\Phi X$ & $28,1 \pm 0,8$ & $19,5 \pm 0,7^{* 1}$ & $20,9 \pm 1,1^{* 1}$ \\
\hline ЛФХ & $4,2 \pm 0,1$ & $6,4 \pm 0,09^{* 1}$ & $5,4 \pm 0,1^{* 1,2}$ \\
\hline ФЭ & $24,0 \pm 1,0$ & $24,2 \pm 0,9$ & $23,4 \pm 1,4$ \\
\hline$\Phi C$ & $28,4 \pm 0,9$ & $17,5 \pm 0,7^{* 1}$ & $22,1 \pm 1,1^{* 1,2}$ \\
\hline ФИ & $4,5 \pm 0,06$ & $3,8 \pm 0,04^{* 1}$ & $4,1 \pm 0,06^{* 1,2}$ \\
\hline ГФЛ & $89,2 \pm 2,7$ & $71,4 \pm 1,9^{* 1}$ & $75,9 \pm 1,7^{* 1,2}$ \\
\hline $\mathrm{CM}$ & $14,1 \pm 0,5$ & $11,9 \pm 0,6^{* 1}$ & $12,7 \pm 0,7^{* 1,2}$ \\
\hline ФЛ & $103,3 \pm 3,3$ & $83,3 \pm 2,4^{* 1}$ & $88,6 \pm 1,9^{* 1,2}$ \\
\hline $\mathrm{X}$ & $32,4 \pm 1,1$ & $40,5 \pm 1,4^{* 1}$ & $38,9 \pm 1,8^{* 1}$ \\
\hline ЭX & $28,1 \pm 1,2$ & $35,9 \pm 1,4^{* 1}$ & $32,3 \pm 2,2^{* 1}$ \\
\hline $\mathrm{TA \Gamma}$ & $13,2 \pm 0,6$ & $16,5 \pm 0,5^{* 1}$ & $17,3 \pm 1,1^{* 1}$ \\
\hline ДАГ+МАГ & $11,0 \pm 0,4$ & $10,0 \pm 0,6$ & $10,5 \pm 0,7$ \\
\hline НЭЖК & $2,9 \pm 0,1$ & $2,8 \pm 0,04$ & $3,0 \pm 0,1$ \\
\hline \multicolumn{4}{|c|}{ Соотношение фракций липидов } \\
\hline ЛФХ/ФХ & $0,15 \pm 0,02$ & $0,33 \pm 0,03^{* 1}$ & $0,26 \pm 0,02^{* 1,2}$ \\
\hline $\mathrm{CM} / \Phi \mathrm{X}$ & $0,5 \pm 0,03$ & $0,61 \pm 0,03^{* 1}$ & $0,61 \pm 0,02^{* 1}$ \\
\hline $\mathrm{CM} / \Phi \mathrm{C}$ & $0,5 \pm 0,01$ & $0,68 \pm 0,04^{* 1}$ & $0,57 \pm 0,02^{* 1,2}$ \\
\hline$\Phi Х / Ф Э$ & $1,17 \pm 0,03$ & $0,81 \pm 0,02^{* 1}$ & $0,89 \pm 0,03^{* 1,2}$ \\
\hline$\Phi X / \Phi C$ & $0,99 \pm 0,03$ & $1,11 \pm 0,02^{* 1}$ & $0,96 \pm 0,04$ \\
\hline ФХ/ФЭ+ФС+ФИ & $0,49 \pm 0,02$ & $0,43 \pm 0,02^{* 1}$ & $0,42 \pm 0,02^{* 1}$ \\
\hline ХС/ФЛ & $0,59 \pm 0,02$ & $0,92 \pm 0,04^{* 1}$ & $0,8 \pm 0,03^{* 1,2}$ \\
\hline
\end{tabular}


При анализе соотношения изученных липидных фракций мембраны эритроцитов выявлено, что до лечения при ХЭ повышается соотношение ЛФХ/ФХ, СМ/ФХ, СМ/ФС, ФХ/ФС и Х+ЭХ/ФЛ, но снижается

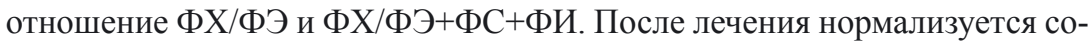
отношение $\Phi \mathrm{X} / Ф С$, корригируется в сторону контрольных показателей отношение ЛФХ/ФХ, СМ/ФС, ФХ/ФЭ и Х+ЭХ/ФЛ, остается без изменения соотношение $\mathrm{CM} / Ф \mathrm{X}$ и ФХ/ФЭ+ФС+ФИ (табл. 2).

У пациенток с ХЭ до начала лечения в эритроцитах установлена активация процессов перекисного окисления липидов (ПОЛ, повышение концентрации МДА и АГП), снижение факторов антиоксидантной защиты (ОАА, активности СОД и каталазы). Кроме этого, установлено повышение уровня $\mathrm{CM}_{\mathrm{ON}}$ и снижение сорбционных показателей мембраны эритроцитов (СЕГ и ССЭ). Проведенное лечение не влияло на измененные показатели антиоксидантной защиты эритроцитов (СОД и ОАА) и корригировало в сторону показателей здоровых доноров остальные исследованные параметры метаболической активности эритроцитов (табл. 3).

Таблица 3.

Метаболические показатели эритроцитов при XЭ до и после лечения $(\mathrm{M} \pm \mathrm{m})$

\begin{tabular}{|c|c|c|c|c|}
\hline \multirow{3}{*}{ Показатели } & \multirow{3}{*}{$\begin{array}{c}\text { Единицы } \\
\text { измерения }\end{array}$} & 1 & 2 & 3 \\
\hline & & $P_{-1000}$ & \multicolumn{2}{|c|}{ Больные } \\
\hline & & Здоровые & До лечения & После лечения \\
\hline МДА & мкмоль/л & $0,39 \pm 0,03$ & $1,1 \pm 0,07^{* 1}$ & $0,7 \pm 0,04^{* 1,2}$ \\
\hline АГП & усл. ед. & $0,22 \pm 0,02$ & $0,89 \pm 0,04^{* 1}$ & $0,76 \pm 0,02^{* 1,2}$ \\
\hline OAA & $\%$ & $35,1 \pm 3,0$ & $25,6 \pm 2,8^{* 1}$ & $27,0 \pm 1,9^{* 1}$ \\
\hline СОД & усл. ед. & $18,9 \pm 0,9$ & $14,1 \pm 1,1^{* 1}$ & $15,2 \pm 1,7^{* 1}$ \\
\hline Каталаза & мккат/л & $24,1 \pm 1,1$ & $17,6 \pm 2,2^{* 1}$ & $20,1 \pm 2,3^{* 1,2}$ \\
\hline $\mathrm{CM}_{\mathrm{NO}}$ & мкмоль/л & $2,4 \pm 0,2$ & $4,9 \pm 0,1^{* 1}$ & $4,1 \pm 0,2^{* 1,2}$ \\
\hline $\mathrm{CE} \Gamma$ & $10^{-12}$ г/эр. & $1,8 \pm 0,06$ & $1,3 \pm 0,04^{* 1}$ & $1,5 \pm 0,05^{* 1,2}$ \\
\hline ССЭ & $\%$ & $33,1 \pm 1,8$ & $18,5 \pm 1,9^{* 1}$ & $22,7 \pm 1,4^{* 1,2}$ \\
\hline
\end{tabular}

Таким образом, можно констатировать, что у пациенток с ХЭ до начала лечения оказались измененными от значений здоровых доноров $90 \%$ показателей структурно-функциональных свойств эритроцитов. Проведенное комплексное традиционное лечение нормализовало 9\% измененных до лечения параметров, корригировало, но не до значений нормы, $55,6 \%$. Без изменения осталось $33,4 \%$ показателей (табл. 1-3). 
Мембрана эритроцита составляет всего $1 \%$ от его веса, хотя роль ее в жизнедеятельности клетки красной крови чрезвычайно велика. Мембрана обеспечивает эластичность эритроцита, прочность, долговечность, способность к растяжению при прохождении через узкие отверстия и каналы, поддерживает внутриклеточный гомеостаз и функциональное состояние эритроцита. Хотя основные структурные особенности биологической мембраны эритроцитов определяются свойствами липидного бислоя, большинство ее специфических функций осуществляется белками. Определяющим фактором слаженного функционирования эритроцитарной мембраны, является строгая упорядоченность расположения белковых макромолекул. Основная часть (до 80\%) периферических белков мембран эритроцитов входит в состав его цитоскелета, который представляет собой эластичную двумерную сеть, соединенную непосредственно с мембраной через взаимодействие с полярными группами интегральных белков и полярными головками липидов. Кроме этого, к периферическим белкам относится ряд эритроцитарных ферментов [11, c. $471-476,12$, с. $7-27]$.

Полученные нами данные свидетельствуют о значительных изменениях со стороны белков, ответственных за структурообразование и стабилизацию мембраны эритроцитов ( $\alpha$ - и $\beta$-спектрин, дематин - основные белки цитоскелета, анкирин, белок полосы 4.1, паллидин), формообразование и гибкость мембраны (актин, тропомиозин), внутриклеточный метаболизм (Г-3-ФД, Г-S-T).

Мембраны эритроцитов содержат внешний и внутренний слои ФЛ, но при этом, распределение их отдельных представителей в мембране асимметрично. Холинсодержашие нейтральные по заряду ФХ и СМ находятся преимущественно в наружном монослое мембраны, тогда как аминофосфолипиды - ФЭ и ФС, а также не содержащий азота ФИ располагаются, в основном, во внутреннем слое. Основополагающая роль в сохранении бислойной организации биологических мембран принадлежит ФХ и СМ. ФХ обладает высокой обменивающей активностью, имеет большое значение для проницаемости мембран, влияет на метаболизм X и играет особую регуляторную роль в процессах ПОЛ в норме и при развитии патологических состояний. Соотношение СМ и ФХ определяет не только осмотическую и гемолитическую устойчивость эритроцитов, но и их термостабильность и продолжительность циркуляции в кровяном русле. ФХ и ФЭ являются специфическими активаторами ряда мембраносвязанных ферментов, оказывают действие на стволовые клетки, увеличивают обра- 
зование очагов кроветворения, активируют систему мононуклеарных фагоцитов, обеспечивают антиокислительную активность липидов мембран эритроцитов. Присутствие ФС необходимо для нормального функционирования большинства изоформ протеинкиназы C, а также $\mathrm{Na}^{+} / \mathrm{K}^{+}$-ATФазы, нейтральной сфингомиелиназы и других ферментов. ФС играет исключительно важную роль в процессе апоптоза эритроцитов (эриптоз), который является одним из способов обновления форменных элементов крови. Избирательное окисление ФС и его последующее перемещение в наружную часть мембраны способствует распознаванию и уничтожению подобных клеток макрофагами и дальнейшему их удалению из циркулирующей крови [13, с. 3-7, 14, с. 334-354, 15, с. 587-602].

Важную роль в регуляции метаболизма играет ФИ, несмотря на низкое содержание в составе ФЛ эритроцитов крови. Более того, во многих клеточных процессах, выступая в роли вторичных мессенджеров, участвуют и продукты распада ФИ. Накопление в мембранах ФИ повышает возможность контроля над транспортом и передачей информации внутрь клетки в виде гуморальных сигналов. Различия в метаболизме и составе ФИ мембраны эритроцитов влияют на физико-химические свойства мембраны, в частности, на ее вязкость и способность связывать ионы кальция, что, в свою очередь, обусловливает изменения функций мембраны. На наружной поверхности мембраны эритроцитов присутствуют также лизоформы ФЛ, в частности ЛФХ, который участвует в регуляции активности ряда связанных с мембраной ферментов, является вторичным посредником трансмембранной передачи сигнала внутри клетки, Вариации содержания ЛФХ могут приводить к изменению топологии мембранной системы - появлению пор. Избыточное количество продуктов гидролиза ФЛ - НЭЖК и лизоформ ФЛ - мощный фактор модификации свойств липидного бислоя и интегральных мембранных белков. Цитолитический эффект ЛФХ, сопровождающийся увеличением проницаемости мембран для органических молекул и ионов, обусловлен сочетанием действия их как поверхностно-активных веществ и ионофоров, вызывающих структурные перестройки липидного компонента и белков в мембранах [12, c. $7-27,15$, с. $587-602,16$, с. $97-118,17$, с. $442-447]$.

Молекулы Х разбросаны по внешней стороне так, что их содержание равно примерно одной молекуле на каждую молекулу ФЛ. Наличие X в бислое способствует вытягиванию насыщенных и ненасыщенных цепей молекул ФЛ, уплотнению бислоя, уменьшает проницаемость для малых водорастворимых молекул и воды, увеличивает упругость и механиче- 
скую прочность бислоя, изменяет активность мембранных белков. Благодаря X мембрана может менять свою форму в ответ на приложенную к ней силу, а в отличие от ФЛ он может быстро перераспределяться между монослоями. Хотя Х делает липидный бислой менее текучим, при его высоких концентрациях он предотвращает слипание и кристаллизацию углеводородных цепей. Х соединяется в мембране эритроцитов с ФЛ, откладываясь в виде холестериновых кластеров между листками мембраны и может нарушать функцию рецепторов и ферментов. Повышение содержания X способствует уплощению дискоидной формы и сферуляции эритроцитов [15, с. 587-602, 18, с. 8-19, 19, с. 17-38].

Зрелые эритроциты не способны синтезировать белки и липиды, поддержание и изменения их содержания и соотношения обусловлено микроокружением эритроцитов, а именно составом плазмы крови, который существенно изменяется при патологии, что в свою очередь оказывает существенное влияние на морфологию клетки, липидно-белковые взаимодействия в мембране эритроцитов и обусловленную последними активность ее ферментных систем [14, с. 334-354, 15, с. 587-602, 20, c. $33-42,21$, с. 51-53].

Во многом полученные нами данные при ХЭ совпадают с аналогичными изменениями белково-липидного спектра мембран эритроцитов, выявленные при других видах патологии [22, с. 64-69, 23, с. 5-87, 24, с. 17-22, 25, с. 296-300]. На этот счет есть предположения о существовании биологической целесообразности эволюционно закрепленного ответа белков и липидов эритроцитов крови на патологические воздействия. Существование однотипной реакции может быть обусловлено запуском универсального ответа на внешнее воздействие, в основе которого, по-видимому, лежит физико-химическая система регуляции иммунного гомеостаза и ПОЛ, функционирующие на всех уровнях организации биологической системы. Поскольку процессы ПОЛ взаимосвязаны с важнейшими физико-химическими свойствами мембран (проницаемость, вязкость, фазовое состояние), то развитие различных патологий сопровождается молекулярными изменениями плазматических мембран клеток. Одними из наиболее чувствительных являются мембраны эритроцитов, способных достаточно быстро изменять состав и в условиях нормального функционировании организма. Компенсаторные изменения в белково-липидном спектре эритроцитов направлены на поддержание жидкокристаллической структуры мембраны, барьерных, рецепторных, сорбционных, транспортных и других свойств и проницаемости мембраны. Однотип- 
ность адаптивных биохимических реакций на уровне белков и липидов является, очевидно, одним из основных путей эволюции живого, обусловливающих отсутствие качественных различий ответа организма на действие внешних факторов. Однако в связи с неодинаковой чувствительностью параметров физико-химической системы регуляции ПОЛ и способностью их к восстановлению масштаб и характер взаимосвязей между тесно скоординированными в норме показателями может существенно различаться не только в зависимости от природы и интенсивности внешнего фактора, но и от исходного физиологического состояния биологической системы, что обусловливает те количественные различия, которые обнаруживаются не только в разных исследованиях, но и зависят от времени начала действия фактора $[12$, с. $7-27,14$, с. $334-354,15$, c. $587-602,26$, c. $3-40,27$, c. $53-65]$.

\section{Заключение}

Выявленные нами изменения содержания и соотношения липидного состава мембраны, в первую очередь, снижение содержания мембранных ГФЛ и СМ, составляющих основу двойного липидного каркаса клеточной мембраны и играющих основную роль в упорядочивании белковых макромолекул и нормальном метаболизме эритроцитов наряду с изменение архитектоники белков приводит к серьезным нарушениям в функциональных свойствах эритроцитов периферической крови уже на ранних стадиях развития ХЭ, о чем свидетельствует повышение процессов ПОЛ и содержания стабильных метаболитов оксида азота, являющихся косвенным показателем уровня NO. Кроме этого, значительно снижение активности ключевых ферментов антиоксидантной защиты (СОД и каталазы) в эритроцитах свидетельствует о развитии внутриэритроцитарного окислительного стресса.

\section{Список литературы}

1. Eckert L.O., Hawes S.E. Endometritis: The clinical-patologic syndrome // Am. J. Obstet. Gynecol. 2002, 186; 4: 690-5.

2. Гомболевская Н.А., Муравьева В.В., Марченко А.А., Анкрикская А.С., Современные возможности этиологической диагностики хронического эндометрита // Акушерство и гинекология. 2012. № 8. С. 40-45.

3. Sharkey A.M., Smith S.K. The endometrium as a cause of implantation failure. Best Pratice Research Clinical Obstetrics Gynecology, 2003, vol. 17, no. 2, pp. 289-307. 
4. Кулаков В.И., Шуршалина А.В. Хронический эндометрит как причина нарушения репродуктивной функции // Гинекология. 2012. Т. 14, № 4. C. $16-18$.

5. Взаимосвязь коррекции иммунных и оксидантных нарушений со структурно-функциональными свойствами эритроцитов при хронических сальпингоофоритах / Конопля А.А., Караулов А.В., Конопля А.И., Гаврилюк В.П. Курск: Изд-во ГОУ ВПО КГМУ Росздрава, 2009. С. 5-36.

6. Тогайбаев А.А, Кургузкин А.В., Рикун И.В. Способ диагностики эндогенной интоксикации // Лабораторное дело. 1988. № 9. С. 22-24.

7. Семко Г.А. Структурно-функциональные изменения мембран и внешних примембранных слоев эритроцитов при гиперэпидермопоэзе // Украинский биохимический журнал. 1998. № 70. С. 113-118.

8. Dodge G.T., Mitchell C., Hanahan D.J. The preparation and chemical characteristics of hemoglobin free ghosts of human eryrhrocytes. Arch. Biochem. Biophys, 1963, no. 100, pp. 119-130.

9. Крылов В.И., Виноградов А.Ф., Ефремова С.И. Метод тонкослойной хроматографии липидов мембран эритроцитов // Лаб. дело. 1984. № 4. C. 205-206.

10. Laemli U.K. Cleavage of structural proteins during the assembly of the head of bacteriophage T4. Nature, 1970, no. 227, p. 680.

11. Smith J.E. Erythrocyte membrane structure, function and pathophysiology. Vet. Pathol, 1987, vol. 24, no. 6, pp. 471-476.

12. Структурно-функциональные свойства эритроцитов в норме и при патологии / Конопля А.И., Прокопенко Л.Г., Долгарева С.А., Локтионов А.Л., Конопля А.А., Гаврилюк В.П. Курск: Изд-во КГМУ, 2011. С. 7-27.

13. Шульгинова А.А., Ласков В.Б., Конопля А.И., Караулов А.В. Фармакологическая коррекция нарушений липидного спектра мембран эритроцитов у пациентов с хронической ишемией на фоне гипертонической болезни. // Эксперементальная и клиническая фармакология. 2016. Т. 79, № 7. С. 3-7.

14. Структурно-функциональная характеристика мембраны эритроцита и ее изменение при патологиях разного генеза / Боровская М.К., Кузнецова Э.Э., Горохова В.Г., Корякина Л.Б., Курильская Т.Е., Пивоваров Ю.И. // Бюллетень ВСНЦ СО РАМН. 2010. Т. 3, № 73. С. 334-354.

15. Шишкина Л.Н., Шевченко О.Г. Липиды эритроцитов крови и их функциональная активность // Успехи современной биологии. 2010. Т. 130, № 6. C. 587-602.

16. Миоинозит и фосфоинозитиды / Швец В.И., Степанов А.Е., Крылова В.Н., Гулок П.В. М.: Наука, 1987. С. 97-118. 
17. Брызгалова Н.Ю., Браже Н.А., Юсипович А.И. Роль цитоплазматических структур эритроцита в изменении сродства гемоглобина к кислороду // Биофизика. 2009. Т. 54, № 3. С. 442-447.

18. Витамины. Эритроциты. Иммунитет / Бровкина И.Л., Быстрова Н.А., Лазаренко В.А., Прокопенко Л.Г. Курск: КГМУ, 2013. С. 8-19.

19. Петров А.М., Зефиров А.Л. Холестерин и липидные плотики биологических мембран. Роль в секреции, рецепции и функционировании ионных каналов // Успехи физиологических наук. 2013. Т. 44, № 1. С. 17-38.

20. Van-Gelder J., Nair C., Dhall D. Erythrocyte aggregacion and erythrocyte deformability modify the permeability of erythrocyte enriched fibrin network // Throm. Res., 1996, vol. 82, no. 1, pp. 33-42.

21. Кушнаренко Н.Н., Говорин А.В., Щербакова О.А. Клиническое значение нарушений состава жирных кислот мембран эритроцитов и углеводного обмена у больных первичной подагрой с артериальной гипертензией // Клиническая медицина. 2012. № 11. С. 51-53.

22. Структурно-функциональные свойства эритроцитов у больных с гнойным верхнечелюстным синуситом / Будяков С.В., Конопля Н.А., Гаврилюк В.П., Конопля А.И. // Курский науч.-практ. вестн. «Человек и его здоровье». 2010. № 3. С. 64-69.

23. Иммунометаболический статус и эритроциты при патологии предстательной железы; коррекция нарушений / Шатохин М.Н., Конопля А.И., Теодорович О.В., Гаврилюк В.П. М.: Изд-во ГОУ ВПО КГМУ Минздравсоцразвития России, 2012. С. 5-87.

24. Конопля А.И., Шульгинова А.А. Хроническая ишемия головного мозга: состояние структурно-функциональных свойств эритроцитов // Патологическая физиология и экспериментальная терапия. 2016. Т. 60, № 1. C. $17-22$.

25. Структурно-функциональные свойства эритроцитов при использовании различных методов многокомпонентной общей анестезии при лапароскопической холецистэктомии у больных с желчнокаменной болезнью / Сумин С.А., Авдеева Н.Н., Быстрова Н.А., Конопля А.И., Комиссинская Л.С. // Анестезиология и реаниматология. 2016. Т. 61, № 4. C. 296-300.

26. Прокопенко Л.Г., Бровкина И.Л., Конопля А.И. Окислительный стресс. Курск: Изд-во ГОУ ВПО КГМУ Росздрава, 2008. С. 3-40.

27. Рязанцева Н.В., Новицкий В.В. Типовые нарушения молекулярной организации мембраны эритроцита при соматической и психической патологии // Успехи физиологических наук. 2004. Т. 1, № 1. С. 53-65. 


\section{References}

1. Eckert L.O., Hawes S.E. Endometritis: The clinical-pathologic syndrome. Am J Obstet Gynecol, 2002, no. 690, 5 p.

2. Gombolevskaja N.A., Murav'eva V.V., Marchenko A.A., Ankrikskaja A.S. Akusherstvo i ginekologija. 2012. № 8, pp. 40-45.

3. Sharkey A.M., Smith S.K. The endometrium as a cause of implantation failure. Best Pratice Research Clinical Obstetrics Gynecology, 2003, vol. 17, no. 2, pp. 289-307.

4. Kulakov V.I., Shurshalina A.V. Khronicheskiy endometrit kak prichina narusheniya reproduktivnoy funktsii. Ginekologiya, 2012, vol. 14, no. 4, pp. 16-18.

5. Konoplya A.A., Karaulov A.V., Konoplya A.I., Gavrilyuk V.P. Vzaimosvyaz' korrektsii immunnykh $i$ oksidantnykh narusheniy so strukturno-funktsional'nymi svoystvami eritrotsitov pri khronicheskikh [Correlation of the correction of immune and oxidant disorders with the structural and functional properties of erythrocytes in chronic salpingo-oophoritis]. Kursk: Izd-vo GOU VPO KGMU Roszdrava, 2009, pp. 5-36.

6. Togaybaev A.A, Kurguzkin A.V., Rikun I.V. Laboratornoe delo, 1988, no. 9, pp. 22-24.

7. Semko G.A. Ukrainskiy biokhimicheskiy zhurnal, 1998, no. 70, pp. 113-118.

8. Dodge G.T., Mitchell C., Hanahan D.J. The preparation and chemical characteristics of hemoglobin free ghosts of human eryrhrocytes. Arch. Biochem. Biophys, 1963, no. 100, pp. 119-130.

9. Krylov V.I., Vinogradov A.F., Efremova S.I. Metod tonkosloynoy khromatografii lipidov membran eritrotsitov. Lab. Delo, 1984, no. 4, pp. 205-206.

10. Laemli U.K. Cleavage of structural proteins during the assembly of the head of bacteriophage T4. Nature, 1970, no. 227, p. 680.

11. Smith J.E. Erythrocyte membrane structure, function and pathophysiology. Vet. Pathol, 1987, vol. 24, no. 6, pp. 471-476.

12. Konoplya A.I., Prokopenko L.G., Dolgareva S.A., Loktionov A.L., Konoplya A.A., Gavrilyuk V.P. Strukturno-funktsional'nye svoystva eritrotsitov v norme $i$ pri patologii [Structural and functional properties of erythrocytes in norm and in pathology]. Kursk: Izd-vo KGMU, 2011, pp. 7-27.

13. Shul'ginova A.A., Laskov V.B., Konoplja A.I., Karaulov A.V. Jeksperemental’naja i klinicheskaja farmakologija. 2016. V. 79, № 7, pp. 3-7.

14. Borovskaya M.K., Kuznetsova E.E., Gorokhova V.G., Koryakina L.B., Kuril'skaya T.E., Pivovarov Yu.I Byulleten' VSNTS SO RAMN, 2010, vol. 3, no. 73, pp. 334-354.

15. Shishkina L.N., Shevchenko O.G. Uspekhi sovremennoy biologii, 2010, vol. 130 , no. 6, pp. 587-602. 
16. Shvets V. I., Stepanov A. E., Krylova V.N., Gulok P.V. Mioinozit i fosfoinoziti$d y$ [Myoinositol and phosphoinositides]. M.: Nauka, 1987, pp. 97-118.

17. Bryzgalova N.Yu., Brazhe N.A., Yusipovich A.I. Biofizika, 2009, vol. 54, no. 3 , pp. 442-447.

18. Brovkina I.L., Bystrova N.A., Lazarenko V.A., Prokopenko L.G. Vitaminy. Eritrotsity. Immunitet [Vitamins. Erythrocytes. Immunity]. Kursk: KGMU, 2013, pp. 8-19.

19. Petrov A.M., Zefirov A.L. Kholesterin i lipidnye plotiki biologicheskikh membran. Rol'v sekretsii, retseptsii i funktsionirovanii ionnykh kanalov. Uspekhi fiziologicheskikh nauk, 2013, vol. 44, no. 1, pp. 17-38.

20. Van-Gelder J., Nair C., Dhall D. Erythrocyte aggregacion and erythrocyte deformability modify the permeability of erythrocyte enriched fibrin network. Throm. Res., 1996, vol. 82, no. 1, pp. 33-42.

21. Kushnarenko N.N., Govorin A.V., Shcherbakova O.A. Klinicheskaya meditsina, 2012, no. 11, pp. 51-53.

22. Budyakov S.V., Konoplya N.A., Gavrilyuk V.P., Konoplya A.I. Chelovek i ego zdorov'e, 2010, no. 3, pp. 64-69.

23. Shatokhin M.N., Konoplya A.I., Teodorovich O.V., Gavrilyuk V.P. Immunometabolicheskiy status $i$ eritrotsity pri patologii predstatel'noy zhelezy; korrektsiya narusheniy [Immunometabolic status and erythrocytes in the pathology of the prostate; Correction of violations]. M.: Izd-vo GOU VPO KGMU Minzdravsotsrazvitiya Rossii, 2012, pp. 5-87.

24. Konoplya A.I., Shul'ginova A.A. Patologicheskaya fiziologiya i eksperimental'naya terapiya, 2016, vol. 60, no. 1, pp. 17-22.

25. Sumin S.A., Avdeeva N.N., Bystrova N.A., Konoplya A.I., Komissinskaya L.S. Anesteziologiya i reanimatologiya, 2016, vol. 61, no. 4, pp. 296-300.

26. Prokopenko L.G., Brovkina I.L., Konoplya A.I. Okislitel'nyy stress [Oxidative stress]. Kursk: Izd-vo GOU VPO KGMU Roszdrava, 2008. 68 p.

27. Ryazantseva N.V., Novitskiy V.V. Uspekhi fiziologicheskikh nauk, 2004, vol. 1, no. 1 , pp. 53-65.

\section{ДАННЫЕ ОБ АВТОРАХ}

Суняйкина Ольга Анатольевна, кандидат медицинских наук, доцент кафедры биологической химии

Курский государственный медицинский университет Минздрава России

ул. Карла Маркса, 3, г. Курск, Курская обл., 305041, Российская Федерачия

9192707253@mail.ru 
Конопля Николай Александрович, доктор медицинских наук, профессор кафедры оториноларингологии Курский государственный медицинский университет Минздрава России

ул. Карла Маркса, 3, г. Курск, Курская обл., 305041, Российская Федерация

konoplya_nikolay@rambler.ru

Сергеева Светлана Леонидовна, кандидат медицинских наук; главный врач, врач акушер-гинеколог высшей категории

Медицинский иентр «Живица»

проспект Победы, 2, г. Курск, Курская обл., Российская Федераиия svet111@inbox.ru

Барсук Анна Александровна, кандидат медицинских наук, врач акушер-гинеколог ОБУЗ ОПЦ Курской области

пр-т Вячеслава Кльюкова, 100, г. Курск, Курская обл., Российская Федерация

dr.annabarsuk@mail.ru

\section{DATA ABOUT THE AUTHORS}

Sunyakina Olga Anatolyevna, Candidate of Medical Sciences, Associate Professor at the Department of Biological Chemistry

Kursk State Medical University of Ministry of Public Health of Russian Federation

3, Karl Marks Str., Kursk, Kursk Region, 305041, Russian Federation 9192707253@mail.ru

SPIN-code: $9912-3519$

ORCID: 0000-0002-6624-234X

ResearcherID: S-7372-2016

Scopus Author ID: 718141

Konoplya Nikolay Alexandrovich, Doctor of Medical Sciences, Professor at the Department of Otolaryngology

Kursk State Medical University of Ministry of Public Health of Russian Federation

3, Karl Marks Str., Kursk, Kursk Region, 305041, Russian Federation 
konoplya_nikolay@rambler.ru

SPIN-code: 1574-0036

ORCID: 0000-0003-4728-6088

ResearcherID: $H-8911-2016$

Scopus Author ID: 349955

Sergeeva Svetlana Leonidovna, Candidate of Medical Sciences, Head Physician, Obstetrics and Gynecology, Doctor of Higher Category Medical Center "Zhivitsa»

2, Prospekt Pobedy, Kursk, Kursk Region, Russian Federation svet111@inbox.ru

SPIN-code: 6077-1487

ORCID: 0000-0002-5607-1612

ResearcherID: $R-2155-2016$

Scopus Author ID: 896713

Barsuk Anna Alexandrovna, Candidate of Medical Sciences, Obstetrics and Gynecology Doctor

Regional Perinatal Center

100, Pr-t Vyacheslav Klykov, Kursk, Kursk Region, Russian Federation drannabarsuk@mail.ru 